\title{
Evaluating Microbial Water Quality and Potential Sources of Fecal Contamination in the Musconetcong River Watershed in New Jersey, USA
}

\author{
Tsung-Ta David Hsu',2, Lee H. Lee ${ }^{1,2}$, Alessandra Rossi ${ }^{1,3}$, Ayuni Yussof ${ }^{1}$, Nancy Lawler ${ }^{4}$, \\ Meiyin $\mathrm{Wu}^{1,2,3^{*}}$
}

\author{
${ }^{1}$ Passaic River Institute, Montclair State University, Montclair, NJ, USA \\ ${ }^{2}$ Department of Biology, Montclair State University, Montclair, NJ, USA \\ ${ }^{3}$ Environmental Science and Management Program, Montclair State University, Montclair, NJ, USA \\ ${ }^{4}$ Musconetcong Watershed Associations, Asbury, NJ, USA \\ Email: *wum@mail.montclair.edu
}

How to cite this paper: Hsu, T.-T.D., Lee, L.H., Rossi, A., Yussof, A., Lawler, N. and Wu, M.Y. (2019) Evaluating Microbial Water Quality and Potential Sources of Fecal Contamination in the Musconetcong River Watershed in New Jersey, USA. Advances in Microbiology, 9, 385-397.

https://doi.org/10.4236/aim.2019.94023

Received: March 7, 2019

Accepted: April 22, 2019

Published: April 25, 2019

Copyright $\odot 2019$ by author(s) and Scientific Research Publishing Inc. This work is licensed under the Creative Commons Attribution International License (CC BY 4.0).

http://creativecommons.org/licenses/by/4.0/

\begin{abstract}
Microbial pathogens and indicators have contributed to major part of water quality degradation in the United States. Located in the northwestern New Jersey, the Musconetcong River has been included in the New Jersey Impaired Waters List or the 303(d) List due to high concentrations of fecal indicator bacteria. Hence, a Total Maximum Daily Load plan was established to address microbial water quality issues in the watershed. The objectives of this study were to assess the current status of microbial water quality and to determine potential sources of fecal contamination in the Musconetcong River Watershed using microbial source tracking techniques. Fifteen sampling events in total were carried out at nine sites throughout the Musconetcong River Watershed in August 2016, July and August 2017. E. coli enumeration was performed to determine the possible presence of fecal contaminations. Microbial source tracking techniques, specifically Canada goose, cow, deer, horse, and human-specific molecular markers, were used for real-time polymerase chain reaction (qPCR) analysis in order to identify and quantify potential sources of fecal contamination. The results indicated that $E$. coli was found present at all nine study sites. Two of the nine sites violated the New Jersey Surface Water Quality Standards in August 2016, while all of the nine sites exceeded the standards in both July and August 2017. Water temperature, dissolved oxygen (DO), and specific conductance at the study sites ranged from $13.5^{\circ} \mathrm{C}$ to $25.3^{\circ} \mathrm{C}$, from $7.7 \mathrm{mg} / \mathrm{L}$ to $13.0 \mathrm{mg} / \mathrm{L}$, and $278.5 \mu \mathrm{S} / \mathrm{cm}$ to $1335.0 \mu \mathrm{S} / \mathrm{cm}$, respectively, at the time of sample collection. E. coli counts
\end{abstract}


were found to be negatively correlated with temperature and specific conductance $(p<0.05)$ but positively correlated with dissolved oxygen, accumulated rainfall within 1 day, rainfall within 2 days, and rainfall within 3 days ( $p$ $<0.05$ ). Higher percentage of presence of human, Canada goose and deer markers were observed at all fifteen sampling events indicating human and wildlife were the two major sources of fecal contaminations in the Musconetcong River Watershed. The study suggested applying restoration measures to reduce fecal contaminations from anthropogenic and wildlife sources in order to improve microbial water quality of the Musconetcong River. However, more frequent and strategic sampling plan is recommended to supply more comprehensive data to aid in future planning of best management efforts on controlling fecal contaminations.

\section{Keywords}

Microbial Water Quality, Potential Sources, Fecal Contamination, Microbial Pathogens

\section{Introduction}

Microbial contaminations have contributed to a major part of water quality impairment in the United States [1], accounting for various drinking and recreational waterborne outbreaks in the US [2]. Sources of contamination were mostly attributed to fecal wastes originated from septic systems, livestock, domestic animals, and wildlife [3]. Conventionally, microbial water quality has been often evaluated using fecal indicator bacteria (FIB), because they are easy to measure as opposed to quantify each and every pathogen. Moreover, the enumeration results showed a clear linkage to fecal contaminations and potential presence of pathogenic microbes [4]. Common FIBs include total coliform, fecal coliform, Escherichia coli (E. coli), and enterococcus [4]. The US Environmental Protection Agency (EPA) has developed microbial water quality criteria using FIBs; in freshwater ecosystems, E. coli is the most commonly used FIB [4] [5]. The Clean Water Act requires states and tribal nations to assess waterbodies for water quality impairment. Once a waterbody is found impaired, the waterbody is listed on the State's Impaired Waters List or the 303(d) List and a Total Maximum Daily Load (TMDL) plan is developed as a planning tool to address the water quality impairment issues [6].

Once an area is identified to be impaired due to high FIB, the next step is to identify the sources of such contamination, so mitigation efforts can focus on eliminating the sources directly. Microbial source tracking (MST) provides the opportunity to identify potential sources of fecal contamination. The results of MST can be applied to aid in the development of a TMDL plan to better mitigate the water quality deterioration [7]. MST approaches include both phenotypic and genotypic methods. Phenotypic typing requires observation of physical and 
biochemical characteristics, including antibiotic resistance and bacteriophage; genotypic typing involves assessment of genetic information, including ribotyping and host-specific molecular markers [7] [8]. Without having to build reference databases and grow bacteria or virus from samples, DNA markers in certain bacteria (e.g. Bacteroidales) associated with fecal materials from specific animal sources have been identified, including human, ruminant, and avian species [9] [10] [11]. In conjunction with real-time polymerase chain reaction (qPCR) analysis, these molecular markers could be used to both identify and quantify sources of fecal contamination in short amount of time. Multiple case studies that utilized various MST methods have been documented across the US for source identification, model development, and prioritizing management practice [7].

Located in northwestern New Jersey, Musconetcong River is a tributary to the Delaware River, encompassing a drainage area of 408.2 square kilometers. Main land uses for the watershed consist of forest (56.0\%), urban (21.4\%), and agriculture (11.6\%) [12]. Historical documents showed that bacterial water quality in Musconetcong River frequently exceeded water quality standards, failing to support primary contact recreation [13] [14]. In 2003, a TMDL plan for fecal coliform were established to address water quality impairment in the Musconetcong River, requiring 93\% reduction of fecal coliform at multiple locations along the River [15]. Since then, various restoration efforts have been undertaken to reduce fecal contamination including implementation of new riparian buffers, erosion control, sinkhole closure and green infrastructure [12]. The objectives of this study were to assess microbial water quality and to determine potential sources of fecal contamination post restoration implementation in the Musconetcong River Watershed. Results from this study would improve understanding the status of microbial water quality and potential sources of contamination in the Musconetcong River Watershed and assist stakeholders to better control the fecal contaminations.

\section{Materials and Methods}

\subsection{Field Sampling}

Nine study sites were selected throughout the Musconetcong River Watershed, New Jersey, based on past water quality monitoring results and local knowledge (Table 1 and Figure 1). Surface water grab samples were collected aseptically into $1 \mathrm{~L}$ sterilized polypropylene bottles at each study site. Five sampling events within a thirty-day time period were scheduled in August 2016, and July and August 2017. Sampling events were independent of weather events. Samples were placed immediately in a cooler filled with ice and transported to the Water Analysis Laboratory of Passaic River Institute at Montclair State University. Water samples were processed within 6 hours of water sample collection and finished processing within 8 hours of collection [16] [17]. Precipitation data were retrieved from New Jersey Weather \& Climate Network at Stewartsville Station 


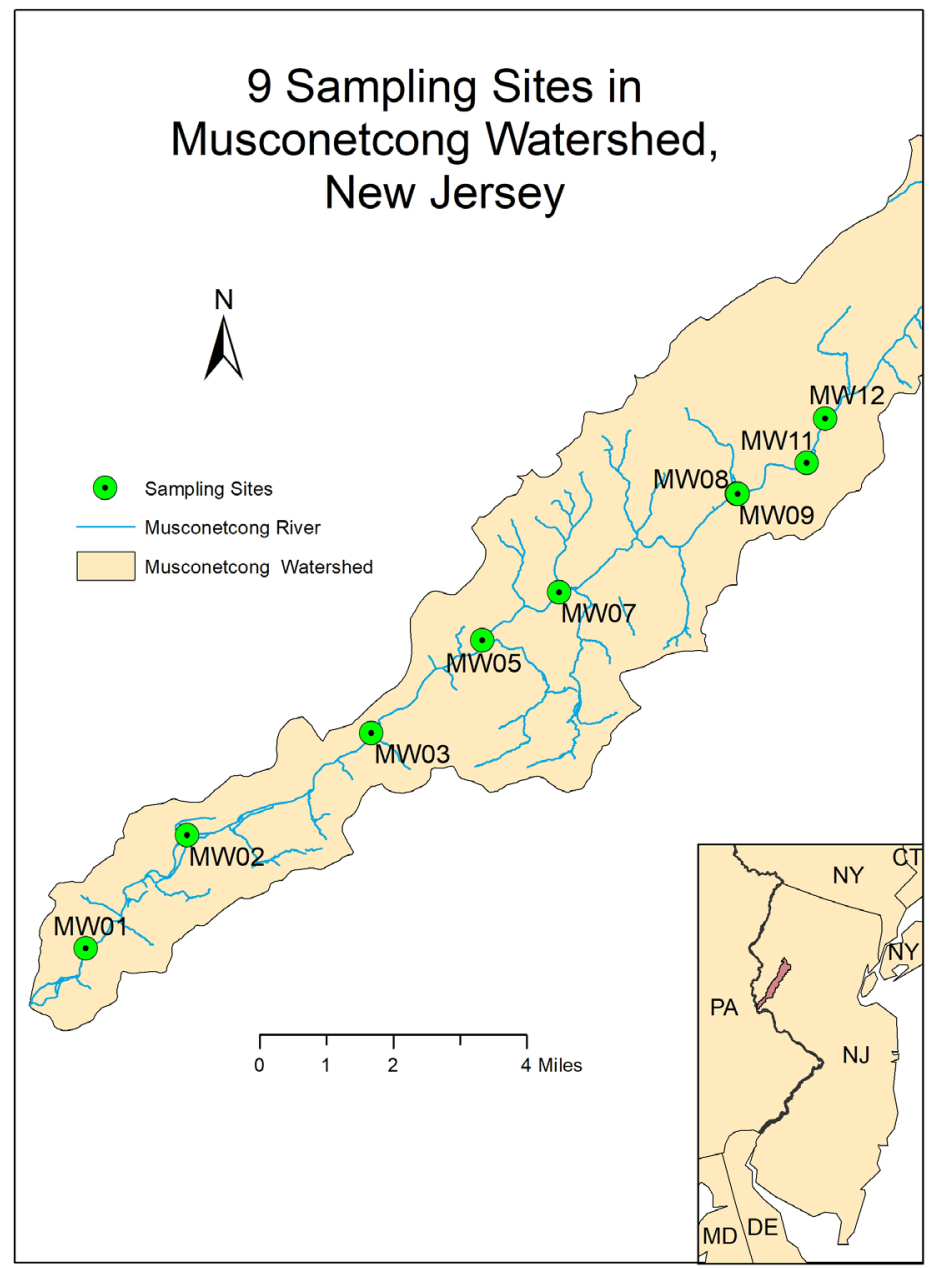

Figure 1. Sampling sites in the Musconetcong Watershed, New Jersey, USA. This map was generated using ArcMap Version 10.6.1 (ESRI, Redlands, CA).

Table 1. Locations of selected nine study sites within the Musconetcong Watershed, New Jersey, USA.

\begin{tabular}{ccccc}
\hline Site ID & Latitude & Longitude & Municipality $^{\mathrm{a}}$ & Dominant Land Use $^{\mathrm{b}}$ \\
\hline MW01 & 40.6047 & -75.1727 & Holland & Forest \\
MW02 & 40.6295 & -75.1442 & Pohatcong & Forest \\
MW03 & 40.6519 & -75.0919 & Bloomsbury & Forest \\
MW05 & 40.6723 & -75.0605 & Bethlehem & Agriculture \\
MW07 & 40.6828 & -75.0386 & Franklin & Agriculture \\
MW08 & 40.7044 & -74.9882 & Franklin & Agriculture, Forest \\
MW09 & 40.7044 & -74.9879 & Franklin & Agriculture, Forest \\
MW11 & 40.7112 & -74.9684 & Hampton & Agriculture \\
MW12 & 40.7209 & -74.9632 & Lebanon & Agriculture \\
\hline
\end{tabular}

${ }^{\mathrm{a}}$ Municipality of sampling sites were based on the access points to sampling locations. ${ }^{\mathrm{b}}$ Dominant land use were estimated from NJDEP 2012 Land Use GIS layer downloaded from Bureau of GIS, Department of Environmental Protection, State of New Jersey (http://www.nj.gov/dep/gis/lulc12.html). The area within $1 \mathrm{~km}$ radius of each sampling location was assessed. GIS processing was conducted using ArcMap Version 10.6.1 (ESRI, Redlands, CA). 
(https://www.njweather.org/, GPS: 40.65537, -75.1163). Distances from this weather station to the sampling locations range from 2.2 to 10.6 miles. Field measurement of temperature, dissolved oxygen, and specific conductance were performed using YSI Pro 2030 (YSI Incorporated, Yellow Springs, Ohio). Meter calibrations were conducted according to the user manual.

\subsection{Field Indicator Bacteria}

E. coli was selected as an indicator of fecal contamination for this study. Water samples were diluted with phosphate buffer ( $\mathrm{PB}, \mathrm{pH} 7.2)$ to one fifth and/or one twenty-fifth of original concentrations. Dilution factors were determined based on previous results and the weather condition at the time of sampling, targeting optimal colony counts between 20 to 60 colony forming units (CFU) per plate. Once dilutions were made, $100 \mathrm{~mL}$ of the original and/or diluted samples were filtered through mixed cellulose ester membrane filters $(0.45 \mu \mathrm{m}, 47 \mathrm{~mm}$, Hach, Loveland, Colorado). Blank $\mathrm{PB}, \mathrm{PB}$ spiked with E. coli and $\mathrm{PB}$ spiked with Pseudomonas aeruginosa were included for quality control purpose as blank, positive control, and negative control, respectively. After filtration, filters were then placed onto petri dishes containing mColiBlue $24^{\circ}$ Broth (Hach, Loveland, Colorado) and incubated at $35^{\circ} \mathrm{C}$ for 24 hours. After the incubation period, the plates were inspected; colonies showing a blue/indigo color were recorded as $E$. coli. The results were reported as colony forming units (CFU) per $100 \mathrm{~mL}$ of water samples.

\subsection{Microbial Source Tracking}

A pair of sampling events in each year were selected for MST analysis (8/16/2016, $8 / 18 / 2016,7 / 11 / 2017$, and 7/25/2017); one was selected to represent a dry weather event and another for a wet weather event. A wet weather event was defined when precipitation occurred within the 48-hour time period prior to water sample collection. Seven-hundred $\mathrm{mL}$ of each water sample were filtered for DNA extraction. Total DNA of the water samples was extracted using DNeasy Power Water Kit (Qiagen, Germantown, MD). The final eluate was $100 \mu \mathrm{L}$. The DNA concentrations and purity were checked with NanoDrop ${ }^{\text {TM }}$ 2000c Spectrophotometers (Thermo Fisher Scientific, Waltham, MA). Real-time polymerase chain reaction (qPCR) analysis was carried out using StepOnePlus Real-Time PCR System (Thermo Fisher Scientific, Waltham, MA). Primers used in this study, including human, cow, deer, Canada goose, and horse were selected or modified from published literature (Table 2) [18] [19] [20] [21]. Master mix stock solutions consisted of 1X PowerUp SYBR Green Master Mix (Applied Biosystems, Foster City, CA) and $10 \mu \mathrm{M}$ of forward and reverse primers. The programs for qPCR started at $95^{\circ} \mathrm{C}$ for $10 \mathrm{~min}$, followed by 40 cycles of DNA denaturation at $95^{\circ} \mathrm{C}$ for $15 \mathrm{sec}$ and reaction at $60^{\circ} \mathrm{C}$ for $1 \mathrm{~min}$. Melting curve programs were added at the end of the reaction to confirm the specificity of amplifications. 
Table 2. Real-time polymerase chain reaction (qPCR) primers used to conduct microbial source tracking in this study.

\begin{tabular}{|c|c|c|c|c|c|}
\hline Species & Primers & Sequence & Target & Amplicon (bp) & References \\
\hline \multirow[t]{2}{*}{ Human } & ForChul & AGATAGTAGGCGGGGTACGG & 16S rRNA Bacteriodes & 61 & modified from [18] \\
\hline & RevChul & AССТTССТСТCAGAAССССТА & & & \\
\hline \multirow[t]{2}{*}{ Cow } & CowM3F & CCTCTAATGGAAAATGGATGGTATCT & 16S rRNA Bacteriodes & 122 & [20] \\
\hline & CowM3R & CCATACTTCGCCTGCTAATACCTT & & & \\
\hline \multirow[t]{2}{*}{ Deer } & Deer Forward & TAACCCGATTCTTCGCCTTCCTC & Mitochondrial DNA (cytb) & 122 & [21] \\
\hline & Deer Reverse & GTCTGCGTCTGATGGAATTCCTGAT & & & \\
\hline \multirow[t]{2}{*}{ Canada goose } & CanadaGooseFor & CTAACATCCAAATCCCTCGACCCA & Mitochondrial DNA (ND2) & 77 & [21] \\
\hline & CanadaGooseRev & TCCTATTCAGCCTCCTAGTGCTCT & & & \\
\hline \multirow[t]{2}{*}{ Horse } & Hof597F & CCAGCCGTAAAATAGTCGG & 16S rRNA Bacteriodes & 129 & [9] [19] \\
\hline & Bac708R & CAATCGGAGTTCTTCGTG & & & \\
\hline
\end{tabular}

Feces from human, cow, deer, Canada geese, and horse were collected locally and their DNA were extracted using QIAamp DNA Stool Mini Kit (Qiagen, Valencia, CA). DNA from stool samples were used as templates to construct plasmid standards for qPCR analysis. Briefly, each target DNA fragment was amplified using corresponding forward and reverse primers (Table 2) in a Veriti Thermal Cycler (Thermo Fisher Scientific, Waltham, MA). Amplified DNA was examined on agarose gel and purified using DNA Clean \& Concentrator (Zymo Research, Irvine, CA). The purified DNA was ligated into NEB ${ }^{\circ}$ PCR Cloning linearized vector (New England Biolabs, Ipswich, MA) and transformed into NEB PCR Cloning competent cells by heat shock transformation (New England Biolabs, Ipswich, MA). The recombinant plasmids were extracted using the QIAprep Spin Miniprep Kit (Qiagen, Valencia, CA). The inserted DNA were sequenced and checked against the Nucleotide BLAST Sequence Analysis Tool on NCBI (https://blast.ncbi.nlm.nih.gov/Blast.cgi) for sequence specificity. DNA concentrations were determined using a NanoDrop ${ }^{\mathrm{TM}}$ 2000c Spectrophotometers (Thermo Fisher Scientific, Waltham, MA). The copy numbers were derived using the following equation:

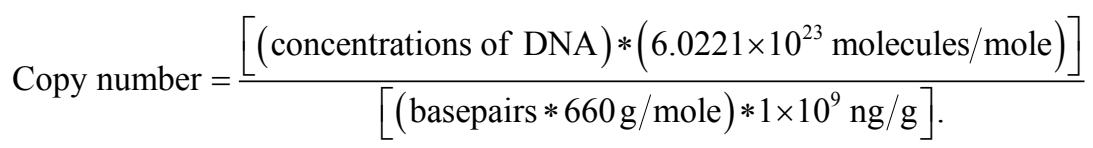

For each species, ten-fold serial dilutions of target species genes with predetermined copy numbers were used to generate standard curves to quantify copy numbers of target species genes from total environmental DNA extract.

Copy numbers of each host-specific marker were derived from standard curves of $\mathrm{Ct}$ (Cycle threshold, obtained from respective qPCR analysis) against standards of known concentrations of respective host-specific markers. For quality control purpose, 1) blank and no-template-control samples were included 2) triplicate samples were performed, 3) the coefficient of determination $\left(R^{2}\right)$ of the standard curves must be greater than $\left.0.99,4\right)$ the coefficient of varia- 
tion (CV) among the triplicate samples must be within 15\%. A sample with copy numbers higher than the respective detection limit was given a calculated copy number (expressed as copy numbers per $100 \mathrm{~mL}$ of water samples). A sample with no detection signal or with copy numbers lower than respective detection limits was absent of fecal markers and a value of zero was assigned for further analysis. A sample with calculated copy number lower than the lowest concentration of standard was considered containing a minimal amount of fecal markers with higher uncertainty for quantitative analysis; therefore those results were excluded from quantitative analysis as suggested by Helsel [22].

\subsection{Statistical Analysis}

Statistical analysis was performed using R language (Version 3.4.4 [23]) using RStudiosoftware (Version 1.0.44 [24]). Shapiro-Wilk test was used to assess the normality of the data distribution [25]. If variables were found to not follow normal distributions, nonparametric Spearman's correlation was carried out to test associations between $E$. coli and other parameters.

\section{Results and Discussions}

\subsection{Field Indicator Bacteria}

The Musconetcong River and its tributaries were classified as FW2 waters under the current New Jersey Administrative Code, designated for primary contact recreation, industrial, agricultural, and public potable water supply (N.J.A.C. 7:9B-1.12). Previous FIBs studies documented high levels of E. coli at various sampling locations within the watershed [12] [13] [14]. This study re-assessed water quality using FIBs in 2016 and 2017. This study found E. coli to be present at all nine sites across the Musconetcong River Watershed, with geometric mean ranging from $84 \mathrm{CFU}$ to $414 \mathrm{CFU} / 100 \mathrm{~mL}$ in August 2016, from 201 to 345 CFU/100mL in July 2017, and from 94 to 202 CFU/100mL in August 2017 (Figure 2). Compared to the New Jersey Surface Water Quality Standards, 2 sites in August 2016 and all sites in both July and August 2017 were found exceeding the water quality standards of geometric mean of $126 \mathrm{CFU} / 100 \mathrm{~mL}$ or the single sample maximum of $235 \mathrm{CFU} / 100 \mathrm{~mL}$ (N.J.A.C. 7:9B-1.14). The water quality at the selected study sites in the Musconetcong River Watershed did not support the designated use for FW2 water or water for primary contact recreation, industrial and agricultural water supplies and public potable water supply.

Precipitation brings in rainwater which can dilute the concentration of contaminants; however, runoffs caused by precipitation can also carry contaminants from surrounding land into the waterway, increasing the amount of contaminations in water. Bushon and others reported significantly higher concentrations of E. coli were caused by storm events among multiple main stem and tributary sites throughout a multi-land use watershed [26]. Hsu and others also documented E. coli levels significantly correlated with preceding rainfall amounts 


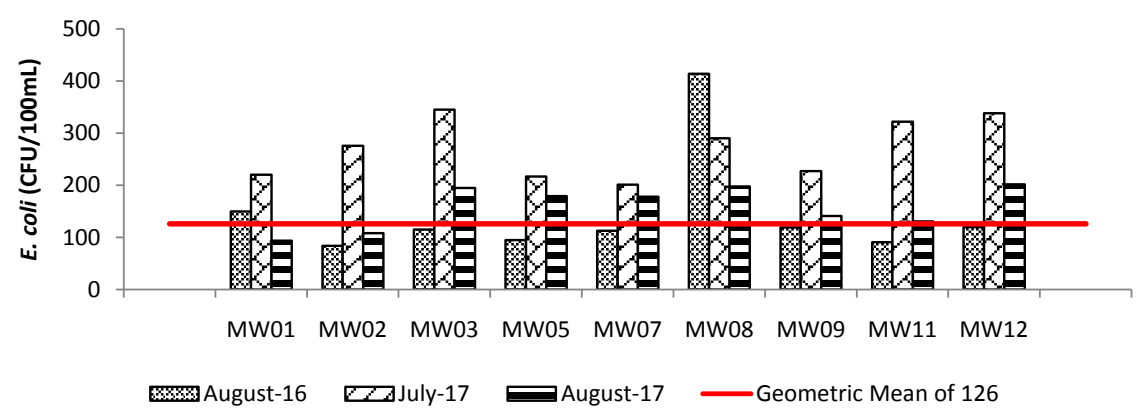

Figure 2. Geometric means of $E$. coli counts documented at the sampling sites in the Musconetcong Watershed, New Jersey, USA. Red line denotes indicate the New Jersey Surface Water Quality Standards Geometric Mean (126 CFU/100mL).

within 24 hours, 48 hours, and 72 hours of water sample collection in an urban watershed [27]. The results of this study coincided with previously reported findings demonstrating positive correlations between $E$. coli and accumulated precipitation within 1 day $(\mathrm{r}=0.23, p<0.05), 2$ days $(\mathrm{r}=0.22, p<0.05)$, and 3 days $(\mathrm{r}=0.29, p<0.05)$ prior to water sample collection, indicating stormwater runoff may have played an important role in transporting $E$. coli from the surrounding drainage area into the Musconetcong River [3]. A greater amount of precipitation was recorded in 2017. The mean accumulated precipitation within 3-day prior to sample collection was substantially higher (0.37 inches) in 2017 than that in 2016 (0.19 inches). The higher amount of precipitations documented in 2017 might have caused a higher percentage of samples exceeding the water quality standards for E. coli in 2017.

This study also recorded water temperature, dissolved oxygen and specific conductance. Water temperature, dissolved oxygen (DO), and specific conductance at the study sites ranged from $13.5^{\circ} \mathrm{C}$ to $25.3^{\circ} \mathrm{C}$, from $7.7 \mathrm{mg} / \mathrm{L}$ to 13.0 $\mathrm{mg} / \mathrm{L}$, and $278.5 \mu \mathrm{S} / \mathrm{cm}$ to $1335.0 \mu \mathrm{S} / \mathrm{cm}$, respectively, at the time of sample collection. Correlation analysis of the study results (Table 3 ) demonstrated E. coli counts were found negatively correlated with temperature $(\mathrm{r}=-0.41, p<0.05)$, negatively correlated with specific conductance $(\mathrm{r}=-0.40, p<0.05)$, but positively correlated with dissolved oxygen $(\mathrm{r}=0.25, p<0.05)$, suggesting higher FIBs at water with a higher dissolved oxygen content, a lower temperature and a lower specific conductance during the summer months at the study sites. Although negatively temperature-dependent $E$. coli survival patterns have been well reported in a variety of water sources, including river and streams [28], the results of the above correlation tests are likely to underestimate the complexity of the river ecosystem.

\subsection{Microbial Source Tracking}

Microbial contaminations can originate from various sources, such as leaking sewer lines, failing septic systems, domestic animals, livestock, wildlife, and stormwater runoff [3]. Arnone and Walling have summarized that a variety of fecal indicator bacteria, including E. coli, Enterococcus, or fecal coliforms, were 
Table 3. The results of correlation analysis between E. coli and environmental parameters (temperature, dissolved oxygen/DO, and specific conductance) in this study.

\begin{tabular}{cccccccc}
\hline & $\begin{array}{c}\text { E. coli } \\
\text { count }\end{array}$ & $\begin{array}{c}\text { Rain } \\
\text { within } 1 \mathrm{~d}\end{array}$ & $\begin{array}{c}\text { Rain } \\
\text { within } 2 \mathrm{~d}\end{array}$ & $\begin{array}{c}\text { Rain } \\
\text { within } 3 \mathrm{~d}\end{array}$ & Temperature & DO & $\begin{array}{c}\text { Specific } \\
\text { conductance }\end{array}$ \\
\hline E. coli count & 1 & $0.23^{*}$ & $0.22^{*}$ & $0.29^{*}$ & $-0.41^{*}$ & $0.25^{*}$ & $-0.4^{*}$ \\
Temperature & -0.41 & -0.04 & $-0.17^{*}$ & $-0.33^{*}$ & 1 & $-0.37^{*}$ & $0.63^{*}$ \\
DO & $0.25^{*}$ & 0.11 & 0.07 & $0.24^{*}$ & $-0.37^{\star}$ & 1 & $-0.31^{*}$ \\
Specific conductance & $-0.4^{*}$ & $-0.21^{*}$ & -0.12 & $-0.31^{*}$ & $0.63^{*}$ & $-0.31^{*}$ & 1 \\
\hline
\end{tabular}

${ }^{*} p<0.05$.

best correlated with swimming-associated gastrointestinal illness in many epidemiological studies worldwide, including sewage or stormwater [2]. For example, a failing wastewater treatment facility caused a waterborne outbreak in Lake Erie, USA, with 1450 gastroenteritis cases reported [29]. On the other hand, fecal materials can also come from wildlife and livestock sources (i.e. Canada geese, deer and cow) and could harbor true pathogens [27] [30] [31] [32] [33]. For example, instead of behaving like a true migratory bird, Canada geese have evolved into residential species, roaming various habitats in U.S. cities from city parks to agricultural fields to gravel pits. Feces are often found carpeting the ground and pose a threat to the water quality of nearby waterways and waterbodies. Various pathogenic E. coli, such as Shiga toxin-producing E. coli (STEC), have been detected and isolated from Canada goose feces [27] [30] [33]. Deer is another wildlife species that has become a pest and a major concern in the U.S. urban and sub-urban communities. In addition to the notorious Lyme disease transmitted to human through the bite of deer ticks, deer feces also harbor a major type of STEC, E. coli O157:H7, which was believed to cause a foodborne outbreak through the consumption of strawberry in 2011 [32]. STEC have also been isolated from cattle feces, which is recognized as the most important natural reservoir for STEC [31].

MST was conducted to identify and quantify potential sources of fecal contamination with an ultimate goal to reduce inputs of fecal pollution. MST was previously used to assess potential sources of fecal contamination in the Musconetcong River Watershed. Unfortunately, only presence or absence of human and bovine fecal markers were included without quantitative results [12]. This study examined and quantified human and bovine as well as three additional markers, Canada goose, deer, and horse, at 9 study sites (both main stem and tributaries) throughout the Musconetcong River Watershed with a goal to discriminate specific sources of fecal contamination at each location. These potential sources were selected with an intention to provide data driven recommendation to aid future water quality management efforts. Different sampling locations may have distinct adjacent land use practices and may require individually designed restoration plan instead of a cookie-cutter approach. Site-specific results would enable stakeholders to develop a site-specific restoration plan targeting specific source(s) of contamination. 
Table 4. Presence of host-specific markers in this study (C: Cow; D: Deer; G: Canada Goose; H: Horse; U: Human).

\begin{tabular}{ccccc}
\hline & 8/16/2016 & 8/18/2016 & $7 / 11 / 2017$ & $7 / 25 / 2017$ \\
\hline MW01 & D, G, H, U & D, G*, H*, U & $\mathrm{U}^{*}$ & None \\
MW02 & D, G, H, U & D, G, U & None & D \\
MW03 & D, G, U & $\mathrm{C}^{*}, \mathrm{D}, \mathrm{G}, \mathrm{U}$ & $\mathrm{U}$ & None \\
MW05 & D, G, U & D, G, H, U & D, U* & U \\
MW07 & D, G, U & D, G, U & D, U* & None \\
MW08 & D, G, H, U & D, G, U & U & C \\
MW09 & D, G, U & D, G, U & None & C \\
MW11 & D, G, U & D, G, U & U & D, U* \\
MW12 & D, G, U & D, G, U & D, U & U \\
\hline
\end{tabular}

*Interpolated copy numbers higher than the lowest concentration of standards.

Based on presence or absence of markers, the human-specific marker accounted for the greatest percentage of presence $(77.8 \%)$ overall in the nine sites for both 2016 and 2017, followed by deer (63.9\%), Canada goose (50.0\%), horse (13.9\%), and cow (8.3\%). MST analysis indicated human and wildlife (deer and Canada geese) were the major sources of fecal contamination among the five markers tested at the study sites; however, sporadic fecal contributions from cow and horse were also substantial.

Table 4 showed presence of host-specific markers in each sampling locations and dates. It is worth highlighting the samples with quantifiable copy numbers of DNA markers, including cow-specific marker were found at MW3 on 8/18/2016; Canada goose-specific marker at MW1 on 8/18/2016; horse-specific marker at MW1 on 8/18/2016; human-specific marker at MW1, MW5, and MW7 on $7 / 17 / 2017$ as well as at MW11 on 7/25/2017. These higher copy numbers of host-specific markers may be attributed to storm events on 8/18/2016 and $7 / 25 / 2017$. Bushon and others reported significant increases in host-specific markers during storm events among multiple main stem and tributary sites throughout a multi-land use watershed [26].

\section{Conclusion}

This study documented a high frequency of bacterial water quality standard violations at the selected nine study sites within the Musconetcong River Watershed. However, this result only reflects temporary status of microbial water quality at the time of water sample collection since the study only encompassed five sampling events within one month in 2016 and ten within two months in 2017. Future study incorporating a more frequent and longer-term sampling scheme is recommended to further confirm the status of bacterial water quality. Additionally, this study only included a pair of dry and wet weather events in each year for microbial source tracking to identify sources of fecal contamina- 
tion. A more frequent and longer-term sampling scheme covering more dry and wet weather events would also help elucidate the impacts of precipitation on study results, especially under the current trend of extreme weather events, as deteriorated water quality is often related to wet weather [34]. Nevertheless, this study has laid the groundwork for examining the bacterial water quality and demonstrating the usefulness of microbial source tracking when determining specific source(s) of fecal contamination. The results of this study will enable environmental managers in the Musconetcong Watershed to identify the best management practices most suited to control the specific fecal contamination identified.

\section{Acknowledgements}

We acknowledge William Penn Foundation for the financial support and Musconetcong Watershed Association for the water sample collections.

\section{Conflicts of Interest}

The authors declare no conflicts of interest regarding the publication of this paper.

\section{References}

[1] USEPA (2016) National Summary of Impaired Waters and TMDL Information. https://iaspub.epa.gov/waters10/attains_nation_cy.control?p_report_type=T\#causes 303d

[2] Arnone, R.D. and Walling, J.P. (2007) Waterborne Pathogens in Urban Watersheds. Journal of Water and Health, 5, 149-162. https://doi.org/10.2166/wh.2006.001

[3] USEPA (2011) Using Microbial Source Tracking to Support TMDL Development and Implementation.

https://www.epa.gov/sites/production/files/2015-07/documents/mst_for_tmdls_gui de_04_22_11.pdf

[4] USEPA (2012) Recreational Water Quality Criteria. https://www.epa.gov/sites/production/files/2015-10/documents/rwqc2012.pdf

[5] USEPA (1986) Ambient Water Quality Criteria for Bacteria. https://www.waterboards.ca.gov/water_issues/programs/tmdl/records/region_5/198 6/ref2435.pdf

[6] Keller, A.A. and Cavallaro, L. (2008) Assessing the US Clean Water Act 303(d) Listing Process for Determing Impairment of a Waterbody. Journal of Environmental Management, 86, 699-711. https://doi.org/10.1016/j.jenvman.2006.12.013

[7] USEPA (2011) Using Microbial Source Tracking to Support TMDL Development and Implementation. https://www.epa.gov/sites/production/files/2015-07/documents/mst_for_tmdls_gui de_04_22_11.pdf

[8] Scott, T.M., Rose, J.B., Jenkins, T.M., Farrah, S.R. and Lukasik, J. (2002) Microbial Source Tracking: Current Methodology and Future Directions. Applied and Environmental Microbiology, 68, 5796-5803.

https://doi.org/10.1128/AEM.68.12.5796-5803.2002 
[9] Bernhard, A.E. and Field, K.G. (2000) A PCR Assay to Discriminate Human and Ruminant Feces on the Basis of Host Differences in Bacteroides prevotella Genes Encoding 16S rRNA. Applied and Environmental Microbiology, 66, 4571-4574. https://doi.org/10.1128/AEM.66.10.4571-4574.2000

[10] Green, H.C., Dick, L.K., Gilpin, B., Samadpour, M. and Field, K.G. (2012) Genetic Markers for Rapid PCR-Based Identification of Gull, Canada Goose, Duck, and Chicken Fecal Contamination in Water. Applied and Environmental Microbiology, 78, 503-510. https://doi.org/10.1128/AEM.05734-11

[11] Mieszkin, S., Yala, J.-F., Joubrel, R. and Gourmelon, M. (2009) Phylogenetic Analysis of Bacteroidales 16S rRNA Gene Sequences from Human and Animal Effluents and Assessment of Ruminant Faecal Pollution by Real-Time PCR. Journal of Applied Microbiology, 108, 974-984. https://doi.org/10.1111/j.1365-2672.2009.04499.x

[12] North Jersey Resource Conservation and Development (RC\&D) Area Inc (2012) Musconetcong River Watershed Protection Plan: Hampton to Bloomsbury. Clinton, NJ.

[13] USGS (2002) Quality of Water in Tributaries to the Upper Delaware River, New Jersey, Water Years 1985-2002.

https://pubs.usgs.gov/fs/2002/fs-090-02/pdf/fs-090-02_ver.1.1.pdf

[14] New Jersey Highlands Council (2008) Water Resources Volume I: Watersheds and Water Quality. https://www.highlands.state.nj.us/njhighlands/master/tr_water_res_vol_1.pdf

[15] New Jersey Department of Environmental Protection (2003) Total Maximum Daily Loads for Fecal Coliform to Address 28 Streams in the Northwest Water Region. https://www.nj.gov/dep/wms/bears/docs/Northwest\%20FC.pdf

[16] American Publication Health Association, American Water Works Association and Water Environment Federation (2012) Standard Methods for the Examination of Water and Wastewater. 22nd Edition, 9-36.

[17] Lee, L.H., Wu, M., Peri, A. and Chu, T.C. (2014) Method Evaluations for Escherichia coli and Coliforms Detection in Northern New Jersey Water Bodies. GSTF Journal of Biosciences, 3, 40-45. https://doi.org/10.5176/2251-3140_3.1.49

[18] Bernhard, A.E. and Field, K.G. (2000) Identification of Nonpoint Sources of Fecal Pollution in Coastal Waters by Using Host-Specific 16S Ribosomal DNA Genetic Markers from Fecal Anaerobes. Applied and Environmental Microbiology, 66, 1587-1594. https://doi.org/10.1128/AEM.66.4.1587-1594.2000

[19] Dick, L.K., Bernhard, A.E., Brodeur, T.J., Santo Domingo, J.W., Simpson, J.M., Walters, S.P. and Field, K.G. (2005) Host Distributions of Uncultivated Fecal Bacteroidales Bacteria Reveal Genetic Markers for Fecal Source Identification. Applied and Environmental Microbiology, 71, 3184-3191.

https://doi.org/10.1128/AEM.71.6.3184-3191.2005

[20] Shanks, O.C., Atikovic, E., Blackwood, A.D., Lu, J., Noble, R.T., Santo Domingo, J.W., Seifring, S., Sivaganesan, M. and Haugland, R. (2008) Quantitative PCR for Detection and Enumeration of Genetic Markers of Bovine Fecal Follution. Applied and Environmental Microbiology, 74, 745-752. https://doi.org/10.1128/AEM.01843-07

[21] Caldwell, J.M. and Levine, J.F. (2009) Domestic Wastewater Influent Profiling Using Mitochondrial Real-Time PCR for Source Tracking Animal Contamination. Journal of Microbiological Methods, 77, 17-22. https://doi.org/10.1016/j.mimet.2008.11.007 
[22] Helsel, D.R. (2012) Statistics for Censored Environmental Data Using MINITAB ${ }^{\circledR}$ and R. 2nd Edition. John Wiley \& Sons, New Jersey.

[23] R Core Team (2016) R: A Language and Environment for Statistical Computing. R Foundation for Statistical Computing. Vienna, Austria. https://www.R-project.org/

[24] RStudio Team (2016) RStudio: Integrated Development for R. RStudio Inc., Boston, MA. http://www.rstudio.com/

[25] Ghasemi, A. and Zahediasl, S. (2012) Normality Tests for Statistical Analysis: A Guide for Non-Statisticians. International Journal of Endocrinology and Metabolism, 10, 486-489. https://doi.org/10.5812/ijem.3505

[26] Bushon, R.N., Grady, A.M.G., Christensen, E.D. and Stelzer, E.A. (2017) Multi-Year Microbial Source Tracking Study Characterizing Fecal Contamination in an Urban Watershed. Water Environment Research, 89, 127-143. https://doi.org/10.2175/106143016X14798353399412

[27] Hsu, T.-T.D., Mitsch, W.J., Martin, J.F. and Lee, J. (2017) Towards Sustainable Protection of Public Health: The Role of an Urban Wetland as a Frontline Safeguard of Pathogen and Antibiotic Resistance Spread. Ecological Engineering, 108, 547-555. https://doi.org/10.1016/j.ecoleng.2017.02.051

[28] Blaustein, R.A., Pachepsky, Y., Hill, R.L., Shelton, D.R. and Whelan, G. (2012) Escherichia coli Survival in Waters: Temperature Dependence. Water Research, 47, 569-578. https://doi.org/10.1016/j.watres.2012.10.027

[29] Fong, T.-T., Mansfield, L.S., Wilson, D.L., Schwab, D.J., Molloy, S.L. and Rose, J.B. (2007) Massive Microbiological Groundwater Contamination Associated with a Waterborne Outbreak in Lake Erie, South Bass Island, Ohio. Environmental Health Perspective, 115, 856-864. https://doi.org/10.1289/ehp.9430

[30] Kullas, H., Coles, M., Rhyan, J. and Clark, L. (2002) Prevalence of Escherichia coli Serogroups and Human Virulence Factors in Faeces of Urban Canada Geese (Branta canadensis). International Journal of Environmental Health Research, 12, 153-162. https://doi.org/10.1080/09603120220129319

[31] Cernicchiaro, N., Cull, C.A., Paddock, Z.D., Shi, X., Bai, J., Nagaraja, T.G. and Renter, D.G. (2013) Prevalence of Shiga Toxin-Producing Escherichia coli and Associated Virulence Genes in Feces of Commercial Feedlot Cattle. Foodborne Pathogens and Disease, 10, 835-841. https://doi.org/10.1089/fpd.2013.1526

[32] Laidler, M.R., Tourdjman, M., Buser, G.L., Hostetler, T., Repp, K.K., Leman, R., Sanadpour, M. and Keene, W.E. (2013) Escherichia coli O157: H7 Infections Associated with Consumption of Locally Grown Strawberries Contaminated by Deer. Clinical Infectious Diseases, 57, 1129-1134. https://doi.org/10.1093/cid/cit468

[33] Hsu, T.-T.D., Rea, C.L., Yu, Z. and Lee, J. (2016) Prevalence and Diversity of Shiga Toxin Genes in Canada Geese and Water in Western Lake Erie Region. Journal of Great Lakes Research, 42, 476-481. https://doi.org/10.1016/j.jglr.2015.12.003

[34] Krometis, L.-A.H., Charackis, G.W., Simmons, O.D., Dilts, M.J., Likirdopulos, C.A. and Sobsey, M.D. (2007) Intra-Storm Variability in Microbial Partitioning and Microbial Loading Rates. Water Research, 41, 506-516.

https://doi.org/10.1016/j.watres.2006.09.029 